\title{
Empire and Landscape in the Tabula Peutingeriana
}

\author{
Silke Diederich
}

\section{$\mathbf{1}$ \\ Introduction: Maps in the Roman Empire}

In the Roman world, maps where perceived as quite exotic. ${ }^{1}$ They were rarely used for practical purposes apart from cadastrial plans, which were often deposited in temples. One of the few exceptions we know of is Frontinus, who had provided himself with aqueduct plans for organizing maintenance works (De aquaeductu urbis Roma 17). But beyond that, maps were not used for administrative matters (as is made clear by the decorative, but geographically incorrect pseudo-maps in the Notitia Dignitatum $)^{2}$ or for organizing journeys (for which the Romans rather relied on written itineraries), and it was not before the Theodosian era - right in the time of the alleged last substantial revision of our Tabula Peutingeriana - that landscape sketches were recommended to military commanders for planning marches through hostile territory. The wordings of these sources imply that those practices were far from common. ${ }^{3}$

Scientific to-scale maps based on astronomic data, like those designed by Eratosthenes or Ptolemaios, were vaguely known among the élites and often admired, but not really understood outside a very small circle of specialists. Even the non-scientific, not-to-scale 'chorographic' maps scoffed at by Ptolemaios (Geog. 1.1) ${ }^{4}$ belonged to the realms of highly accomplished scholarship, to sacral contexts, and to imperial propaganda, even though they became somewhat more familiar during the Empire and in late antiquity. In spite (or, perhaps, because) of being little understood by the many, maps were highly

1 See K. Brodersen, Terra Cognita: Studien zur römischen Raumerfassung (Hildesheim 2003, and ed.). The sources quoted in this paper have been analyzed more fully in S. Diederich, 'Kartenkompetenz und Kartenbenutzung bei den römischen Eliten - Teil 1', Orbis Terrarum 16 (2018), 55-136 and S. Diederich, 'Kartenkompetenz und Kartenbenutzung bei den römischen Eliten - Teil 2', Orbis Terrarum 17 (2019), 101-184. The respective literature is quoted there.

2 Paper forthcoming in the conference proceedings by M. Jelusic, A. Kaiser and S. Roggo (eds.), Ruling an Empire in a Changing World: Studies on Origin, Impact, and Reception of the Notitia Dignitatum.

3 Veg. mil. 3.6.1-4; Anon. Peri strategias 20.8.

4 See M. Rathmann, 'The Tabula Peutingeriana in the mirror of ancient cartography. Aspects of a reappraisal', in K. Geus and M. Rathmann (eds.), Die Vermessung der Oikumene (Berlin 2013), 203-222.

(C) SILKE DIEDERICH, 2022 | DOI:10.1163/9789004411449_021

This is an open access chapter distributed under the terms of the CC BY-NC 4.o liçensęe. Diederich - 9789004411449 
prestigious to a degree that their trustworthiness (veritas) became proverbial. ${ }^{5}$ This was partly due to the god-like view on the earth from 'above' they were felt to convey. ${ }^{6}$ This reputation naturally rendered a map an ideal medium for imperial propaganda.

It is probably no coincidence that the earliest map we know of in Rome was a votive offering dedicated to Jupiter in the temple of the Mater Matuta, bestowed by Tiberius Sempronius Gracchus as a gift of gratitude for his recent conquest in 174 BCE. ${ }^{7}$ It consisted of a forma Sardiniae, as Livius reports, using the technical term forma "land register map" we find, for instance, in the Corpus Agrimensorum. This word choice, connoting a document of real estate property, pronounces an official claim on Sardinia as the rightful possession of the Roman people.

Agrippa's now-lost world map, displayed in the Porticus Vipsania "for Rome to behold", extended this claim to the whole orbis terrarum (Plin. nat. 3.17 orbem terrarum urbi spectandum). It contained measurements of provinces and cities as well as landscape features, such as waterbodies with their perimeters, rivers with their lengths, prominent mountain ranges and references to fauna and flora (e.g., crocodiles), hereby symbolizing Rome's domination over both humanity and nature.

The same probably applies for the Aethiopiae forma commissioned by Nero in the course of an expedition he conducted in order to explore the sources of the Nile, which contained mileages and information about trees (Plin. nat. 12.19), and for the situs depicti (either landscape paintings or maps), Nero had him sent from the Portae Caucasiae, today Darial Gorge (wrongly labelled Portae Caspiae as Plin. nat. 6.40 notes). These geographic depictions may also be interpreted as a means of symbolic appropriation of the area depicted, like a kind of trophy.

Propaganda and higher education blend in the map advertised by Eumenius in 297 CE. The Gallic rhetor pleaded with the emperor to let him restore his school in Augustodunum, urging as an argument the display of a world map in its porticus - obviously a rather unique feature - in which his students could see and admire every day the progresses made by the Roman rulers in conquering and pacifying the world. In Eumenius' map, provinces, seas and landscapes served as a showcase for imperial military and political achievements. ${ }^{8}$

5 E.g., Auson. Grat. act. 2.9: [...] ut qui terrarum orbem unius tabulae ambitu circumscribunt aliquanto detrimento magnitudinis, nullo dispendio veritatis.

6 Prop. 4.3.37-38; Apul. mund. 1.

7 Liv. 41.28.8-10.

8 Eum. Paneg. 9.20-21: Videat [...] iuventus et cotidie spectet omnes terras et cuncta maria et quidquid invictissimi principes urbium gentium nationum aut pietate restituunt aut virtute devincunt aut terrore devinciunt. [...], omnium cum nominibus suis locorum situs, spatia, 
It is important to keep these cartographic traditions in mind in order to understand the Tabula Peutingeriana. ${ }^{9}$ This curious map is a case sui generis in the history of cartography, since it is our only surviving large-size Roman world map, as our copy, the Codex Vindobonensis 324, drawn around 1200 CE, is the replica of a late antique original (with an intermediary copy state in Carolingian times). Even its format is unique: The eleven surviving segments of the parchment scroll (the left-most part having been lost) together are about 6,75 m long, but only $34 \mathrm{~cm}$ high (fig. 20.1). Accordingly, the ancient world from Spain to India is represented with extreme distortions. Here we can grasp the above-mentioned otherwise poorly recorded tradition of ancient nonscientific not-to-scale 'chorographic' maps, originating from outside the highly elitist schools of the mathematical geography developed by Eratosthenes or Ptolemaios. Therefore, it allows an unparalleled insight into the geographical world view of a non-specialist public among Rome's educated elites.

For our recent digital reproduction, please follow the following link (last accessed on March 26, 2021): https://www.arcgis.com/home/webmap/ viewer.html? webmap $=6354474772$ a14968a5a2o1ad3926ee $8 \mathrm{f} \&$ extent $=$ $0.2885,-0.0367,0.3202,-0.01944^{10}$

The TP has been a riddle for scholars since its rediscovery by the Humanist Conrad Celtis, who bequeathed it to his friend Konrad Peutinger in 1507. There are, for instance, many blatant anachronisms: Pompei, distroyed in $79 \mathrm{CE}$, is still there, even marked as an important urban center with a double tower

intervalla descripta sunt, quidquid ubique fluminum oritur et conditur, quacumque se litorum sinus flectunt, qua vel ambitu cingit orbem vel impetu inrumpit oceanus. Ibi fortissimorum imperatorum pulcherrimae res gestae per diversa regionum argumenta recolantur, dum calentibus semperque venientibus victoriarum nuntiis revisuntur gemina Persidos flumina et Libyae arva sitientia et convexa Rheni cornua et Nili ora mutifida [...]. Nunc enim, nunc demum iuvat orbem spectare depictum, cum in illo nihil videmus alienum.

$9 \quad$ For an annotated bibliography on the Tabula Peutingeriana see Oxford Bibliographies s. v. The most recent state of research has been summarised by M. Rathmann, 'Die Tabula Peutingeriana: Stand der Forschung und neue Impulse', in E.N. Akdogu Arca, N. Gökalp Özdil and B. Takmer (eds.), Vir Doctus Anatolicus: Studies in Memory of Sencer Sahin (Istanbul 2016), 714-735. See as well M. Rathmann, 'Neue Perspektiven zur Tabula Peutingeriana II', Orbis Terrarum 18 (2020), 198-251.

10 Further recent editions are E. Weber, Tabula Peutingeriana: Codex Vindobonensis 324, mit Kommentarband (Graz 1976); F. Prontera, Tabula Peutingeriana: Le Antiche Vie del Mondo (Florence 2009, 2nd ed.); M. Rathmann, Tabula Peutingeriana: Die einzige Weltkarte aus der Antike. Eingeleitet und kommentiert (Darmstadt 2018, 3rd ed.). For other digital representations see https://peutinger.atlantides.org/map-a/ and https://www.tabula-peuti ngeriana.de/index.html?lang=de (last accessed on March 26, 2021). 


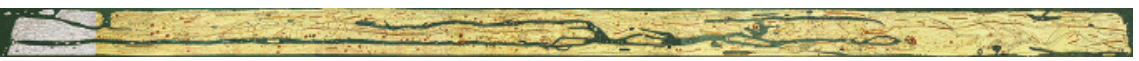

FIGURE 20.1 The Tabula Peutingerina according to the drawn edition by Konrad Miller.

Ulrich Harsch, Bibliotheca Augustana, CC-PD-Mark 1.o

pictograph, while Constantinople already appears as Constantinopolis, as from $337 \mathrm{CE}$ on. Augustean districts in Italy coexist with province nomenclature from the reforms of Diocletianus etc.

This leads to the conclusion that the TP as we know it is the product of several stages of copying and reworking, ${ }^{11}$ the prototype possibly dating as far back as the early Hellenistic period according to Rathmann, ${ }^{12}$ as the basic physical-geographic structures, mainly the shape of the land masses, largely mirror the state of geographical knowledge in the ard century BCE. This basic design has been largely preserved during the different stages of transmission, since it was much more difficult for a copyist to change the overall layout of the continents than to simply add, delete or update single toponyms. Thus, in every copy stage, new items had been supplemented while, due to the notorious conservatism in ancient geographic thought, old entries have also been preserved. Since maps were scarcely designed for practical purposes, up-todateness was not essential.

Major re-workings have so far been detected mainly from Augustean/early imperial time, the reign of the Severi, Diocletianus, Constantine, and perhaps Valens (Antiochia). To distinguish these multiple chronological 'layers' of the TP by means of a careful analysis of each of the about 3800 map entries is one of the tasks of our ongoing DFG funded research project "Commentary on the Tabula Peutingeriana". ${ }^{13}$ The last substantial making over, however, very likely dates to the reign of Theodosius II, when the map received its present form (except for some minor later alterations and - many - copy errors), ${ }^{14}$ as we

11 P. Arnaud, 'L'origine, la date de rédaction et la diffusion de l'archétype de la Table de Peutinger', Bulletin de la Sociéte Nationale des Antiquaires de France 1 (1988), 302-321.

12 M. Rathmann, 'Neue Perspektiven zur Tabula Peutingeriana', GeoAnt 20-21 (2011-2012), 83-102, referring to F. Gisinger, 'Peutingeriana', $R E$ 19,2 (1938), 1405-1412, here: 1408.

13 For further information, please see https://www.ku.de/ggf/geschichte/altegesch/dfg-pro jekt-tabula-peutingeriana/ (last accessed on March 26, 2021).

14 E. Albu, 'Rethinking the Peutinger Map', in R.J.A. Talbert and R.W. Unger, (eds.), Cartography in Antiquity and the Middle Ages (Leiden and Boston 2008), 111-119 and E. Albu, The Medieval Peutinger Map: Imperial Roman Revival in a German Empire (New York 2014) argues in a different direction. According to Albu, the TP was the remodeling of a Carolingian map commissioned probably by the medieval Staufer dynasty. Presenting some interesting aspects and observations, however the counterargument for TP being a late Roman map are much stronger, see above passim as well as, for instance, the review 
learn about a world map commissioned by this emperor on the occasion of his $15^{\text {th }}$ consulate, $435 \mathrm{CE}$, in a poem transmitted by the Carolingian monk Dicuil. There are robust arguments that the map praised by the anonymous poet was the late antique model of our Tabula Peutingeriana..$^{15}$ The panegyrical tone in this dedication poem is even enhanced in comparison to Eumenius': It extolls Theodosius' superior intellect that accomplished to create such a masterpiece of an all-comprehensive world map with all its seas, mountains and rivers, as well as harbors, fords and cities (all items we also find in the TP). ${ }^{16}$ Here, just like in Eumenius's work, we find the blending of the propagandistic and the intellectual aspirations involved in displaying a world map, a demonstration of power as well as of geographical knowledge, ${ }^{17}$ fitting perfectly into the cultural and educational policy of Theodosius, who in 425 re-founded the bilingual 'university' of Constantinople, augmented its library, and had an appreciation especially of geographic learning. ${ }^{18}$

written by E. Weber, 'Ein neues Buch und das Datierungsproblem der Tabula Peutingeriana', Tyche 27 (2012), 209-216.

15 A plausible hypothesis since the Venice 1591 edition by Markus Welser; recently, for instance, E. Weber, 'Die Datierungen des antiken Originals der Tabula Peutingeriana', Orbis Terrarum 14 (2016), 229-258 (with sources and literature).

16 Theodosius II/Dicuil 5,4 = Geographi Latina Minores 19-20 (ed. Riese) = Patrologia Latina Minores 5 p. 84 Baehrens (435 n. Chr.), ed. J. Tierney, Dicuili liber de mensura orbis terrae (Dublin 1967):

Hoc opus egregium, quo mundi summa tenetur,

Aequora quo montes fluvii portus freta et urbes

Signantur, cunctis ut sit cognoscere promptum,

Quidquid ubique latet. Clemens genus, inclita proles

Ac per saecla pius, totus quem vix capit orbis,

Theodosius princeps venerando iussit ab ore

Confici, ter quinis aperit cum fascibus annum.

Supplices hoc famuli, dum scribit pingit et alter,

Mensibus exiguis veterum monimenta secuti,

In melius reparemus opus culpamque priorum

Tollimus ac totum breviter comprendimus orbem:

Sed tamen hoc tua nos docuit sapientia, princeps.

17 On this 'encyclopedic' aspect of the Tabula see M. Schuol, 'Imaginationen: Die Tabula Peutingeriana', in W. Crom and S. Jacobs (eds.), Weltenwandel: Die Karte. Perspektiven, Potentiale, Projektionen (Frankfurt am Main 2018), 246-258, esp. 255.

18 See G. Traina, 'Mapping the world under Theodosius II', in C. Kelly (ed.), Theodosius II. Rethinking the Roman Empire in Late Antiquity (Cambridge 2013), 155-171. 


\section{3}

\section{Maps and Their 'Internal' Semantics}

Our ancient sources concerning maps strongly suggest that the TP, too, was not meant for practical use but rather for educational and, above all, propagandistic purposes. Obviously, the smaller the practical use of ancient maps, the more essential was their symbolic meaning, the message they conveyed and the way they 'told' the world to their beholders. So Jacob is right in stating that ancient maps have an underlying "retorica d'una forma", based on a semantics in which their political, philosophical or religious massages were encoded. Maps follow the rules of discourse, as they convert geographic texts into a pictorial representation. ${ }^{19}$ Thus map-making may be regarded as a kind of translation, transforming verbal geographical descriptions into dots and lines. ${ }^{20}$ Its semiotic system consists of certain formulas for describing the world, such as the shape of the oikumene, the continents, the coastlines, and of a repertoire of geometric and metaphoric patterns for describing countries and islands (e.g., Sardinia formed as a footprint), of pictographs for mountain ranges, woodlands or different towns and cities, ${ }^{21}$ many of which are also known from other kinds of topographic depictions, for instance, on coins, mosaics, wall paintings, reliefs and book illustrations like in the Corpus agrimensorum and the Notitia Dignitatum. So a map resembles a text, based on a sign system similar to a language, in which the single elements, e.g., pictograms and toponyms, are analogical to words, and their arrangement in relation to each other resembles a grammar. It might be not a coincidence that some of the most renowned cartographers in the ancient world, Krates of Mallos, Dikaiarchos and Eratosthenes, have been philologists as well.

\section{A Frontier City: Mainz and Its Surroundings on the Tabula} Peutingeriana

These short preliminary considerations might help to understand the puzzling way landscape is represented in the TP, starting from the example of the border city of Moguntiacum, before discussing the physical-geographic features in this map in general.

\footnotetext{
19 C. Jacob, 'Carte greche', in F. Prontera (ed.), Geografia e geografi nel mondo antico (Rome and Bari 1983), 47-68, here $5^{2}$.

$20 \quad$ Jacob 1983, op. cit. (n. 19), 6 o.

21 Jacob 1983, op. cit. (n. 19), 53.
} 


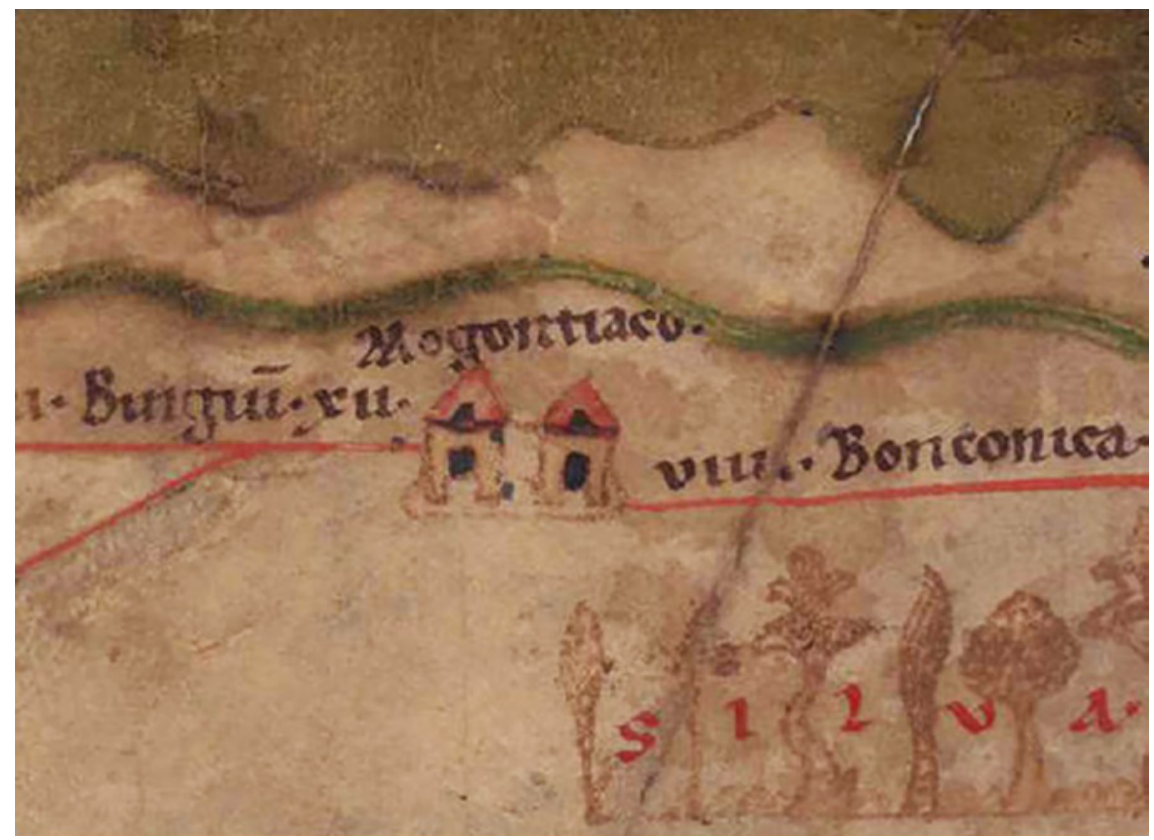

FIGURE 20.2 Mainz/Mogontiacum, Germany. The copyright to the images of the Tabula Peutingeriana in this contribution is held by the DFG-project "Kommentar zur Tabula Peutingeriana/Commentary on the Tabula Peutingeriana" of S.

Diederich and M. Rathmann

Mogontiacum (Fig. 20.2, segment 2A2 Mogontiaco, here in the separative ablative) is one of the oldest Roman settlements in Germania, situated at the river Rhine, which is tilted by approx. $45^{\circ}$ in order to fit its full length into the heavily compressed format of the map.

On the right of Mogontiaco, there is Bononica (perhaps modern Nierstein?), then follows Borbetomagus (Worms), on the left Bingium (Bingen) and Vosavia (Oberwesel), all with distance figures between them, like generally throughout the TP. Mogontiacum is one station on a long route following the Rhine course, brimming with a chain of settlements, nearly all of them on the left bank (fig. 20.3), making the river appear as a hallmark of civilization and the lifeline of the region.

Mogontiacum is distinguished by a double tower vignette, like Trier (2A1 Augusta Tresvirorum) and Cologne (2A1 Agripina), highlighting, perhaps, its function as the govenor's residence of the Provincia Germania Superior from the reign of Domitianus (81-96 CE). After the middle of the third century, however, Mogontiacum turned back to his former status as a frontier stronghold. Abandoned under Iulianus $(361-363 \mathrm{CE})$ or Valentinianus $(364-375 \mathrm{CE})$, it was conquered in 368 und $406 \mathrm{CE}$. Here on the TP, however, it is represented 


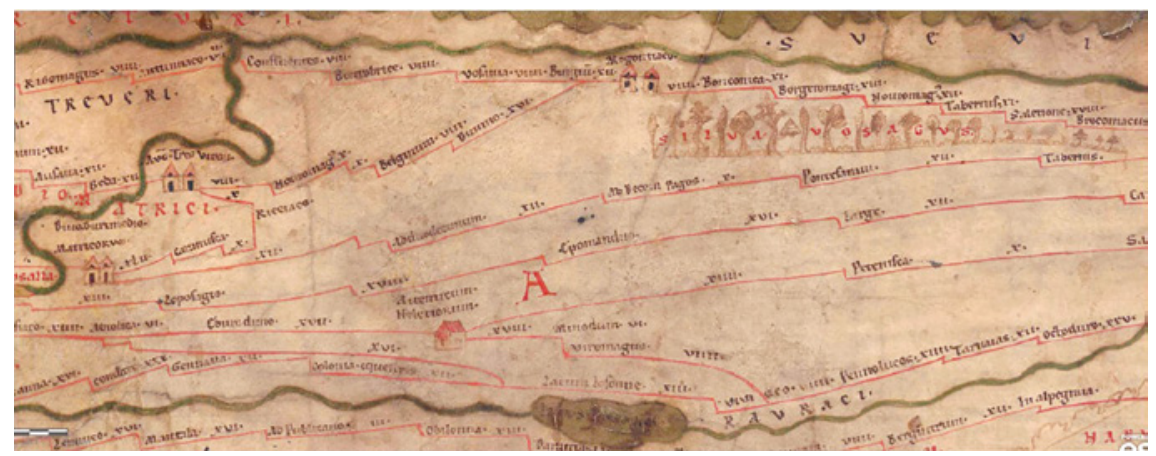

FIGURE 20.3 River Rhine with settlements

COPYRIGHT SEE FIG. 20.2

as in its heydays before the middle of the third century, but at the same time it is already a front-line outpost like after $360 \mathrm{CE}$ and before its destruction in 368. The propagandistic message in Theodosian times (435 CE): Moguntiacum is still standing.

Above Moguntiacum, beyond the river Rhine, there is only a narrow strip of land left, peopled with savage tribes before the icy ocean begins, the lifehostile northern end the world.

The river Main (Moenus), of little use for transport, is missing. But on the right below Moguntiaco one is surprised to find the Silva Vosagus $(2 \mathrm{~A} 2 / 3)$, the late antique name for the French mountain range of Vosges. It is depicted as a chain of tree symbols based on the zigzag line that in the TP is the marker for mountainous areas. The Vosges are, of course, misplaced here; they are supposed to be further down and left (they actually lie sw. of Mainz). ${ }^{22}$ But the map maker obviously considered such woodlands to be a characteristic of Germania since no other mountain forests of this kind are recorded on the Tabula, except the German Black Forest (2A $5 / 6$ Silva Marciana). So, according to the semantics of this map, and ancient geographic thought in general, the Vosagus fits in perfectly here. They underline the map's message, which represents the Rhine and its settlements as an outpost of civilization between savage tribes and deep wilderness. ${ }^{23}$

22 Oddly, they are depicted a second time in $2 \mathrm{~A} 1$ as the unnamed brown mountain symbol, from which the Fluvius Musalla (Mosella, today the river Mosel) springs.

23 The trees that symbolize these woodlands do not seem to represent indigenous fauna, see K. Miller, Itineraria Romana. Römische Reisewege an der Hand der Tabula Peutingeriana (Vienna 1916), 143. They resemble the trees of paradise in some of the early medieval Kosmas-Indikopleustes-maps and some illustrations in the Corpus agrimensorum. 


\section{Some Observations on the Function of Landscape Features in the Tabula Peutingeriana}

Looking at Mainz, we have already observed some characteristics in the representation on landscape on the TP: Elements of physical geography, such as mountains and rivers, as well as seas and lakes are often not placed were they should be expected, even taking into account the map's elongated and squatted format. That raises the question whether those misplaced landscape features serve merely for decoration, as many scholars suppose, or whether they have a semiotic function. ${ }^{24}$

Strabo 2.5.17 highlights the importance of physical-geographical features for giving contour to the earth, above all the sea:

The sea more than anything is a geographer and modeler of the land by carefully outlining the gulfs, open waters, straits, and likewise isthmuses, peninsulas, and promontories; but both the rivers and the mountains assist the sea herein. It is through such natural features that we gain a clear conception of continents, nations, favorable positions of cities, and all the other ornaments with which our geographical map is filled. ${ }^{25}$

And indeed, in the TP the seas both surround the whole oikumene and delineate its inner structure. But conceptualizing a land map, not a sea map, the map maker has shrunken even the vast world-encompassing okeanos to almost a non-entity (fig. 20.1). The perilous Mediterranean Sea, too, has been reduced

24 On the landscape features in the TP see K. Miller, Die Weltkarte des Castorius genannt die Peutingersche Tafel (Ravensburg 1887), 86-89; W. Kubitschek, 'Karten', RE 10.2 (1919), 2022-2149, here 2132-2135; P. Barrière, 'Lignes de terre et lignes d'eau d'après la Table de Peutinger', REA 45 (1943), 91-105; L. Bosio, La Tabula Peutingeriana.Una descrizione pittorica del mondo antico (Rimini 1983), 25-79; P. Arnaud, La cartographie à Rome (Paris 1990), 563-580; R.J.A. Talbert, Rome's World. The Peutinger Map Reconsidered (Cambridge 2010), 102-108.

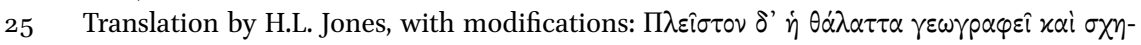

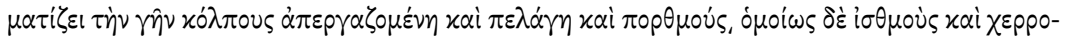

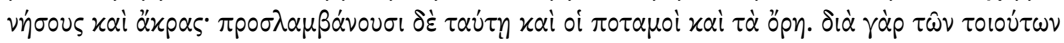

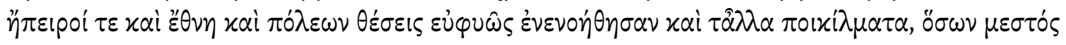

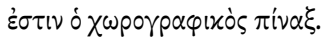




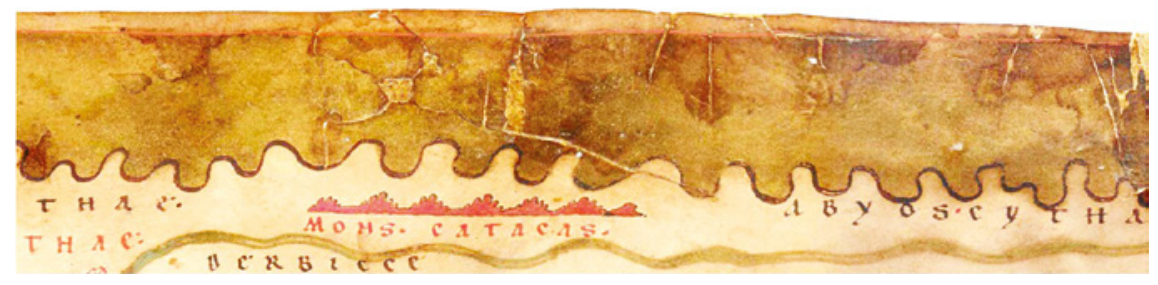

FIGURE 20.4A Northern ocean

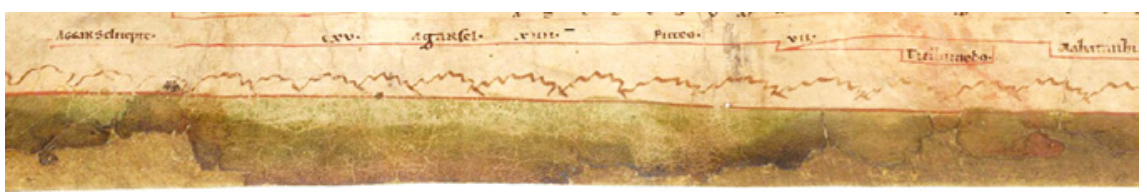

FIGURE 20.4B Northern ocean

to a reassuringly harmless thin slip, controlled by seaports and inhabited islands. Of course, reducing the size of the water bodies is an inevitable result of the map's squatted format - or could it be that this format has actually been chosen because it creates this impression?

The coastline, different from what we would expect after reading Strabo, is symbolized only by a stylized wave pattern, which rarely provides an even approximately realistic depiction of bays and promontories. Namely the northern ocean, which occupies the entire upper rim of the map, is highly simplified into a horizontal wave line (fig. 20.4). That might have been done because every map viewer believed to know anyway what was beyond the northern fringe of the oikumene: Nothing but frozen sea, ${ }^{26}$ way too cold for human beings to exist.

The southern margin of the map is a different case. In the south of Africa, a mountain range pictogram runs from Segment 1 to the start of 9, and from there onwards to the Red Sea, which leads to the Indian Ocean. ${ }^{27}$ What lays beyond those wide African mountains, nobody could know for sure, since the scattered reports concerning this terra incognita were widely regarded as little trustworthy. So it seemed safest to follow the authority of the renown Stoic philosopher and Homer philologist Krates of Mallos, who taught that along the

26 E.g., Plu. Thes. 1.1; Crates frg. 34a, ed. H.J. Mette, Sphairopoiia: Untersuchungen zur Kosmologie des Krates von Pergamon (Munich 1936) = Geminus, Isagoge 15-16; Cic. rep. 6.21; Macr. Somn. 2.5.17.

27 See Talbert 2010, op. cit. (n. 24), 88. 


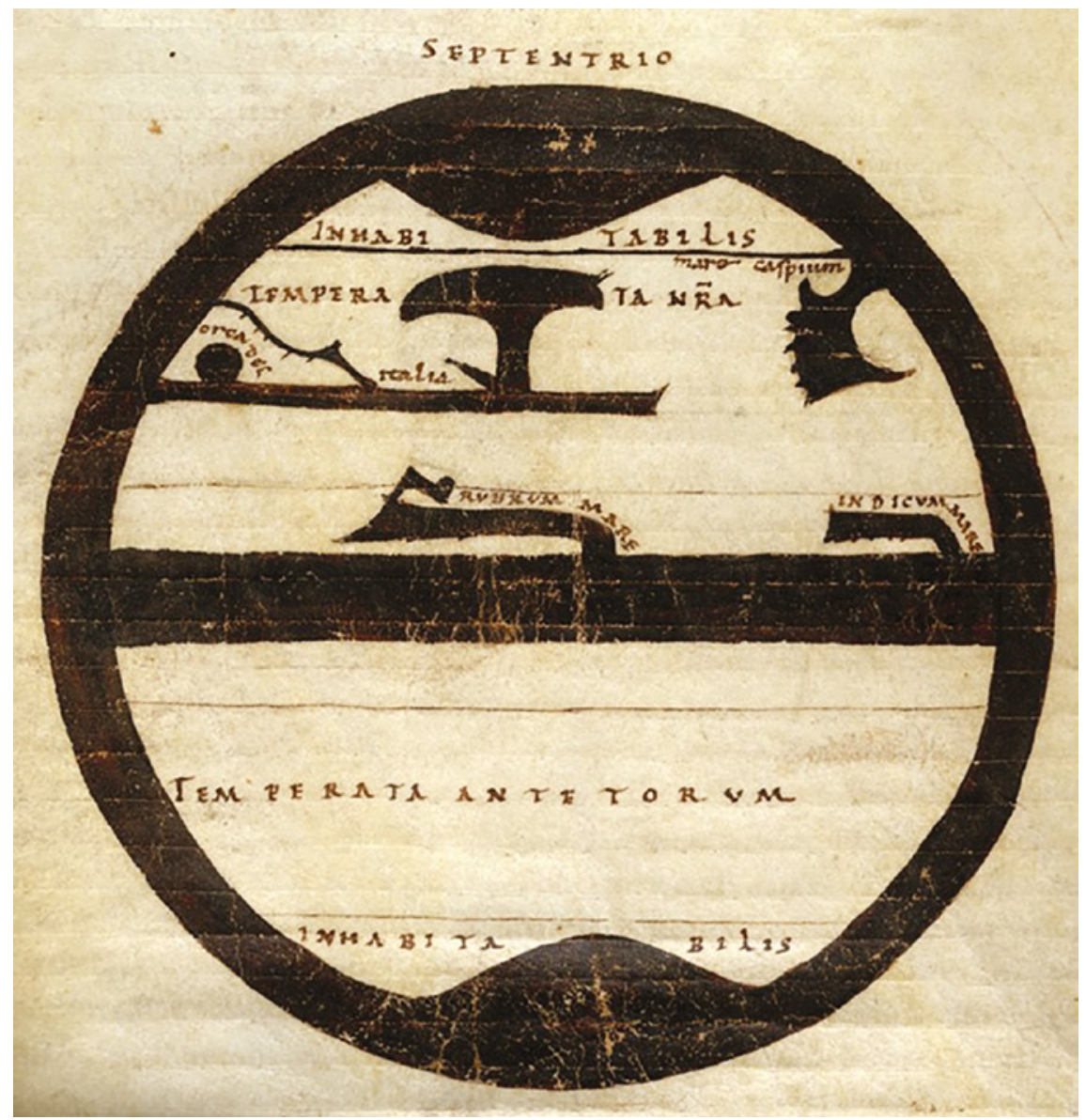

FIGURE 20.5 Macrobius Map, BL Harley 2772, fol. 70 v.; reprint concession given to DFG-project "Kommentar zur Tabula Peutingeriana/Commentary on the Tabula Peutingeriana" of S. Diederich and M. Rathmann

equator stretched the torrent zone, scorching everyone who dared to cross it. ${ }^{28}$ In spite of better information by Hanno, Eratosthenes, Strabo ${ }^{29}$ and other sources, this theory was still enormously influential in Late Antiquity and the Middle Ages (fig. 20.5). That might account for the map maker's decision to draw a barrier of mountain symbols here to mark the limits of human access.

28 Crates (frg. 34a, ed. Mette op. cit. [n. 26]) = Geminus, Isagoge 15-16; cf. Cic. rep. 6,21; Macr. Somn. 2,5,17.

29 Geminus, Isagoge 16.33. 
Deserts, too, are markers for the limits of civilization in ancient maps. ${ }^{30}$ On the $\mathrm{TP}$, we read in the far east: campi deserti et inhabitabiles propter aquae inopiam $(1 \mathrm{OB} 2)$, where probably the Mesopotamian desert is meant, but misplaced here. There are similar entries for the Persian $\left(\mathrm{nB}_{1}\right)$ and the Arabian deserts $\left(\mathrm{1}_{3} \mathrm{C}_{3}\right)$ in the deepest south, and the legend Solitudines Sarmatarum in the farthest north (today: Banat, Romania), above the river Danube ( $\left.5 \mathrm{~A}_{5}-6 \mathrm{~A} 1\right)$. These kind of entries are well-known from medieval maps, and they were evidently frequent in antique ones, too, for Plutarchos, Theseus 1.1 ridicules them as a common ruse of mapmakers to mask their ignorance about these regions.

At the limits of the world we also find a corresponding pair of salt lakes, far in the north (near modern Burukschun) and deep in the south (Sebkha Tauorgha) in Libya. ${ }^{31}$ (fig. 20.6).

\section{Frontier Sanctuaries}

In Roman thought, borders are precarious places. They separate the familiar 'within' from the uncanny 'without'. Thus, they even have their own god: Terminus. Some limits, however, are adamantly fixed for mankind by the Divine Powers, where trespassing would be hubris. So on the TP we read: (fig. 20.7) $11 \mathrm{~A}_{3}$ Ara Alexandri and $11 \mathrm{~B}_{4} / 5$ Hic Alexander responsum accepit: usque quo, Alexander ("At this place Alexander received the prophecy: How far, Alexander?"), alluding to a popular legend, which belonged to the standard repertoire of the Alexander histories and novels ('A $\mathrm{\lambda} \varepsilon \xi \xi^{\prime} \nu \delta \rho \varepsilon \varepsilon \alpha$ 'E $\sigma \chi \alpha$ ' $\tau \eta$, close to modern Khujand, Tajikistan). These frontier sanctuaries have their own special pictograms. But in the TP, the Roman roads both above and beneath the Alexander altars reach beyond those hallmarks of human conquest, right up to the Okeanos in the farthest East, till the end of the world. The message is clear: On Roman roads it is safe to boldly go where no one has gone before, not even Alexander the Great, the explorer par excellence. What the divine powers denied Alexander they bestowed on the Roman Empire. So Eumenius could

$30 \quad$ Prop. 4.3.39; Plu. Thes. 1.1; Eum. Paneg. 9.21; Anydros Iulius Honorius, Sphaera frg. A 13 p. 32 Geographi Latina Minores (ed. Riese).

$31 \quad 8 \mathrm{~A}_{4}$ lacus salinarum ... "Saltpan lake. Here salt is self-generating". Its southern counterpart lays in $6 \mathrm{C}_{4}$ Saline immense que cum luna crescunt et decrescunt "huge salt flats, which rise and fall with the moon". 


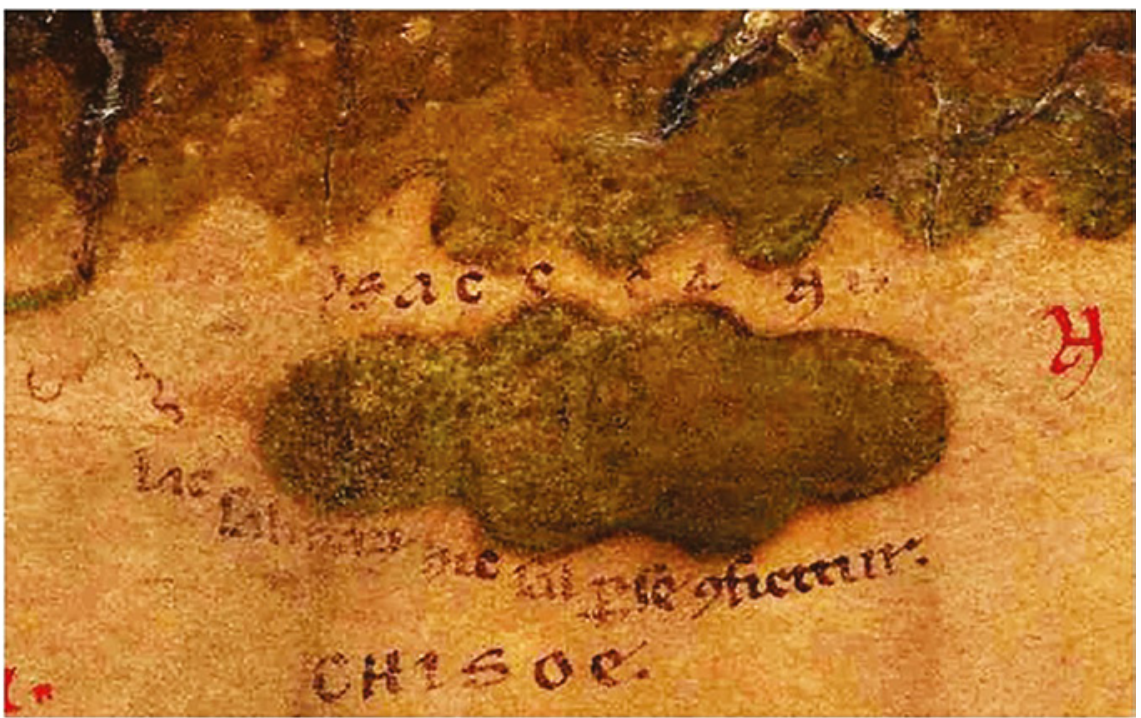

FIGURE 20.6A Salt lake at the northern border of the world

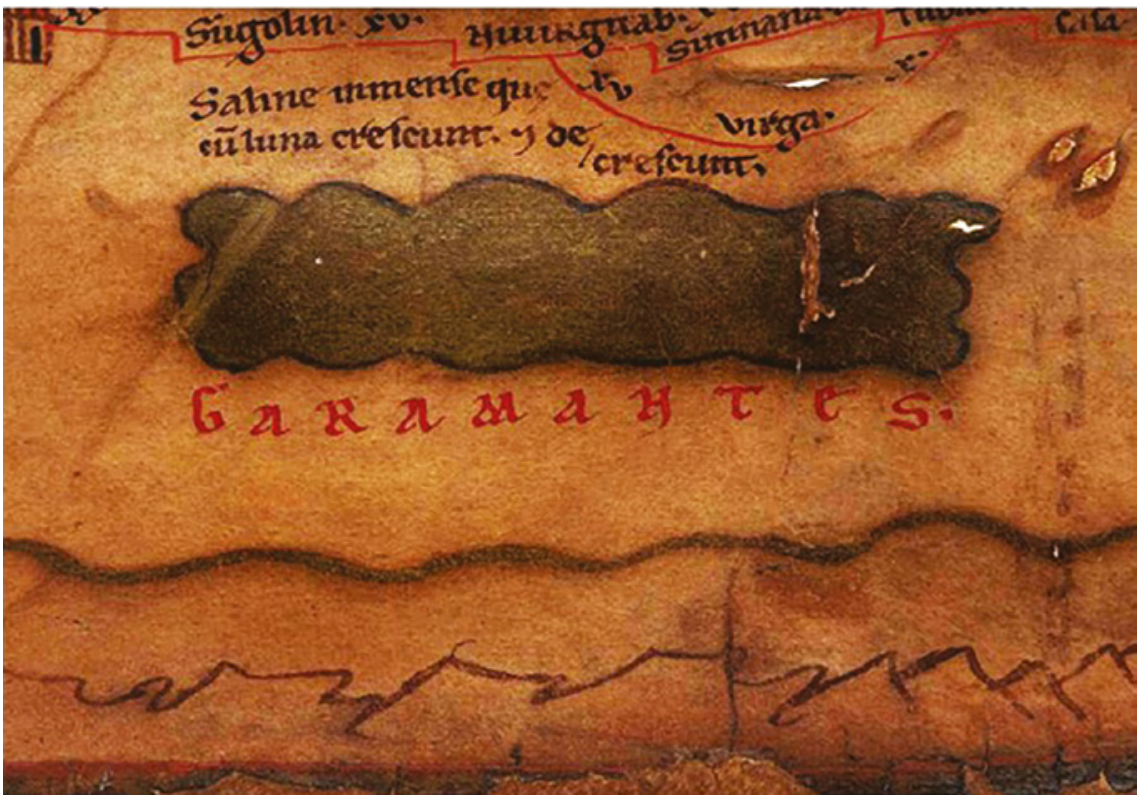

FIGURE 20.6B Salt lake in Libya in south 


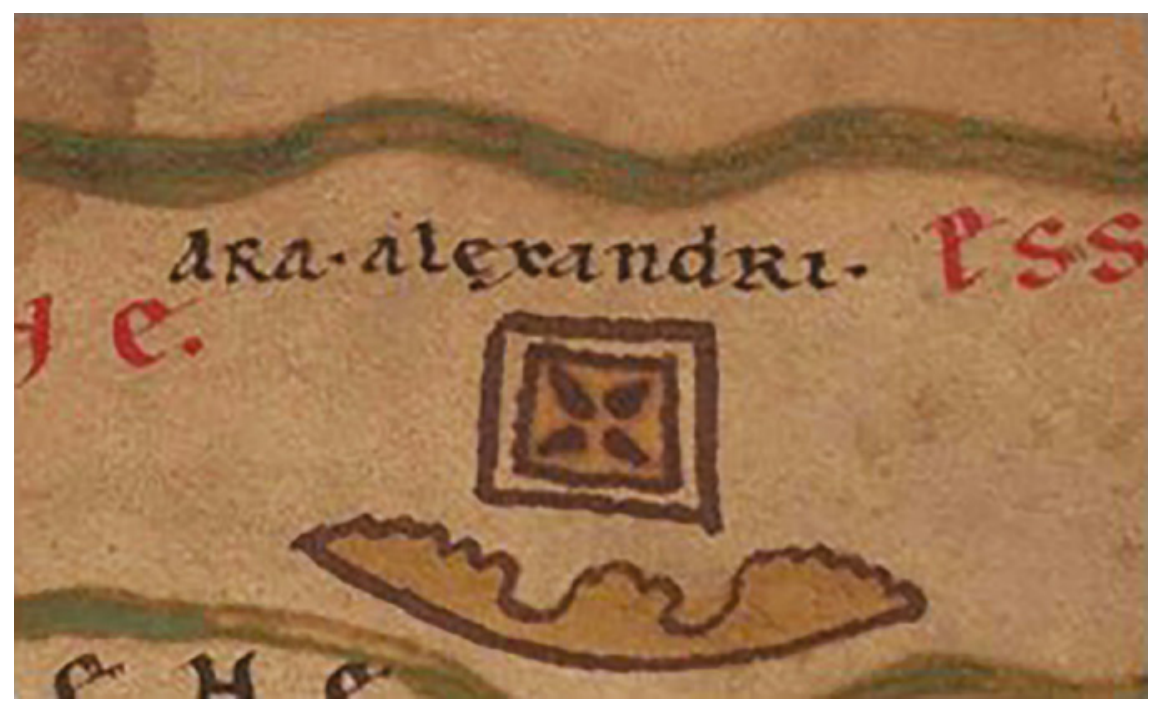

FIGURE 20.7A Alexander's prophecy, part 1

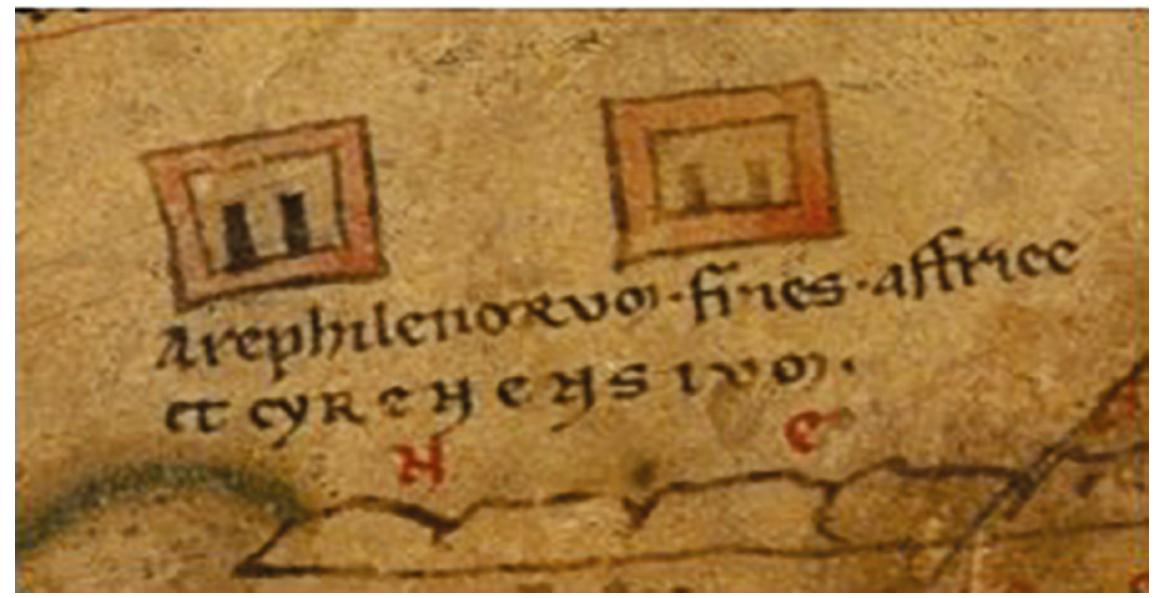

FIGURE 20.7B Alexander's prophecy, part 1 


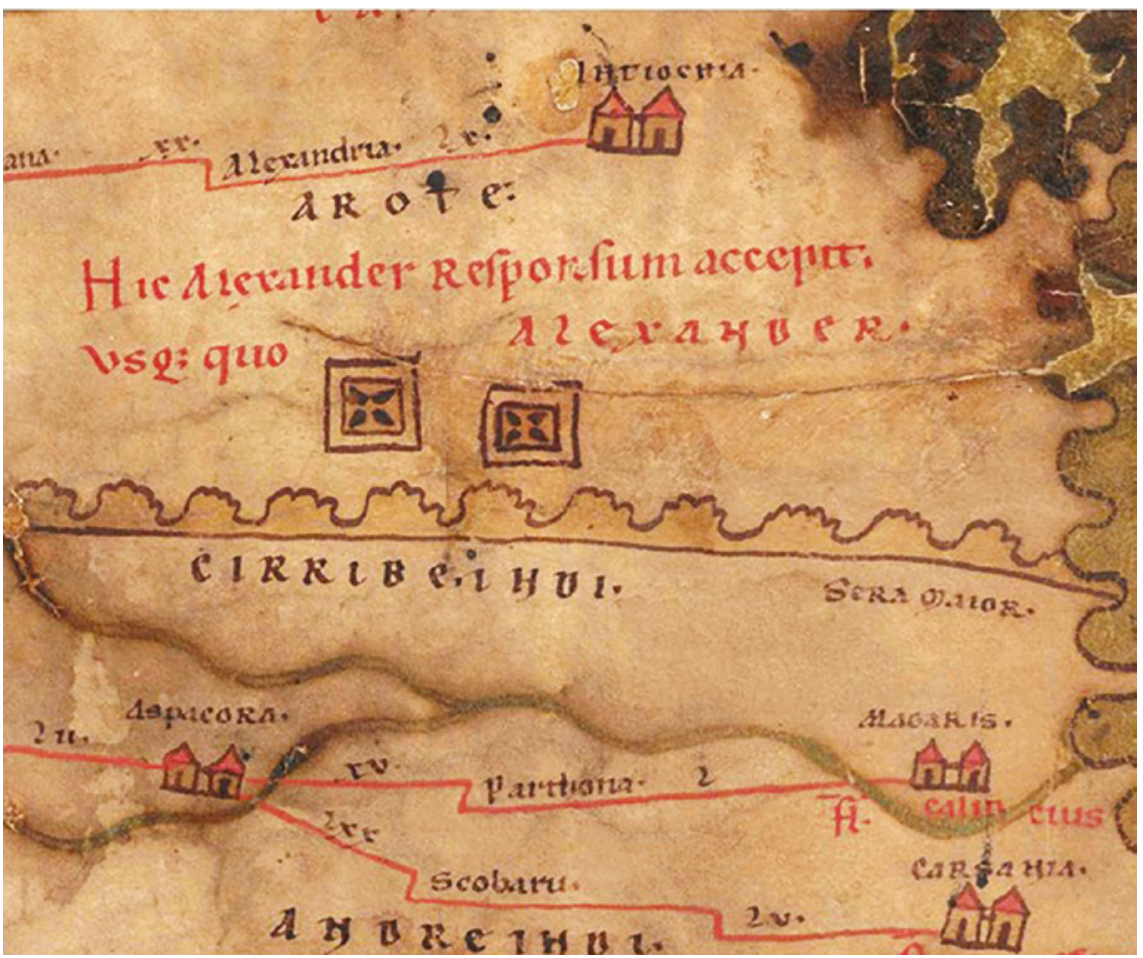

FIGURE 20.7C Alexander's prophecy, part 3

write in in his above-mentioned Panegyricus (Paneg. 9,21) Nunc enim, nunc demum iuvat orbem spectare depictum, cum in illo nihil videmus alienum ("For now, now at last, we take pleasure in beholding a world map, since we see nothing anymore in it that is alien to us"), and the eulogist of the Theodosius map addressed his pious emperor as a genius, totus quem vix capit orbis ("whom the whole world cannot comprehend"). This is Rome's legitimate birthright: an imperium sine fine, an Empire without limits. ${ }^{32}$

32 The only two explicit mentions of the Roman frontiers are in $\mathrm{TP} 10 \mathrm{C} 2$ Are (a) e fines romanorum, written in a desert in the middle of nowhere where no sensible person would like to be and Fines exercitus syriatic(a)e et conmertium Barbaror(um) at the southern end of the world. For the historical background see E. Weber, 'Areae fines Romanorum', in R. Bollinger and B. Truschnegg (eds.), Altertum und Mittelmeerraum: Die antike Welt diesseits und jenseits der Levante (Stuttgart 2006), 219-227. 


\section{$9 \quad$ Rivers and Mountain Ranges as Border Markers}

Rivers in general have significance as natural boundaries according to Strabo (15.1.26), and even more so in the TP, where no actual boundary lines are drawn between peoples, countries or provinces. Yet the position of rivers in the TP is in most cases far from being exact, ${ }^{33}$ and frequently even their names are missing, although some of them are supposed to be inferred from the names of homonymous travelling posts at their crossings, such as ${ }_{5} \mathrm{~B}_{5}$ Ponte Avfidi or $8 \mathrm{~A} 2$ Adherbas $\mathrm{Fl}$ (umen). ${ }^{34}$ In these cases, rivers, like mountains, are foremost seen as obstacles to be overcome by means of road stations. This apparent nonchalance in drawing rivers does not seem to be unusual for an antique map, as even the one Vitruvius (8.2.6) used obviously contained substantial errors.

Nevertheless, rivers in the TP are not drawn at random. As Ilyushechkina ${ }^{35}$ and Schuol ${ }^{36}$ have stated, they often have a semantic function. Parallelisms and symmetries appear between the Rhine in the far north and Nile in the south of the inhabited world, which both are depicted to spring from a lake. Of even greater importance in ancient and medieval geographic thought are Tanais (Don) and Nile because they divide the oikumene in its three continents, Asia, Europe, and Africa. Both spring from a mountain symbol, the Nile originating from Lacus Nusaptis (perhaps today Tana, source of the Blue Nile) surrounded by a mountain chain. Their analogy is underlined by similar legends: $\left(7 \mathrm{~A}_{5}\right)$ Flum Tanais qui diuidit asiam et europam and (8C1): Fl(uvius) Nilus qui diuidit asiam et libiam (fig. 20.8). A further parallel between these two distant regions is phrased explicitly in ${ }_{7} \mathrm{C}_{5}$ Hij montes subiacent paludi simili meotidi per quem nilus transit ("These mountains skirt a marsh, similar to the Maeotis/Sea of Assov, through which the Nile flows.") Here, the map maker combines the Nile with a swamp, just like its northern counterpart, the Tanais.

Of the mountain ranges drawn on the Tabula, only 23 out of 138 are labeled, two of them, Mons Oliveti ( $\left.9 \mathrm{C}_{1}\right)$ and Mons Syna/Sinai (8C4), are Christian

33 See Bosio 1983, op. cit. (n. 24), 55 .

34 L. Bosio and G. Rosada, 'La fonte nella fonte. L'Italia fisica nella descrizione della Tabula Peutingeriana', in F. Nicolis and R. Oberosler (eds.), Archeologia delle Alpi. Studi in onore di Gianni Ciurletti (Trento 2018), 325-336.

35 See https://www.hsozkult.de/conferencereport/id/tagungsberichte-8594?utm_source =hskhtml\&utm_medium=email\&utm_term=2020-1\&utm_campaign=htmldigest\&utm _source=hskhtml\&utm_medium =email\&utm_term=2020-1\&utm_campaign $=$ html digestand (last accessed on March 26, 2021. An article is forthcoming in the periodical Orbis Terrarum).

36 M. Schuol, 'Indien und die großen Flüsse auf der Tabula Peutingeriana', Orbis Terrarum 14 (2016), 92-154. 


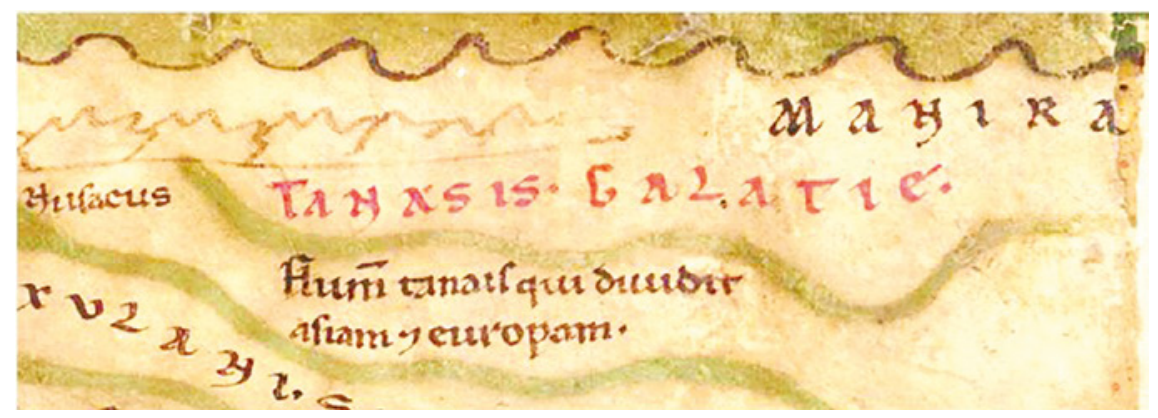

FIGURE 20.8A River Tanais divides Asia and Europe

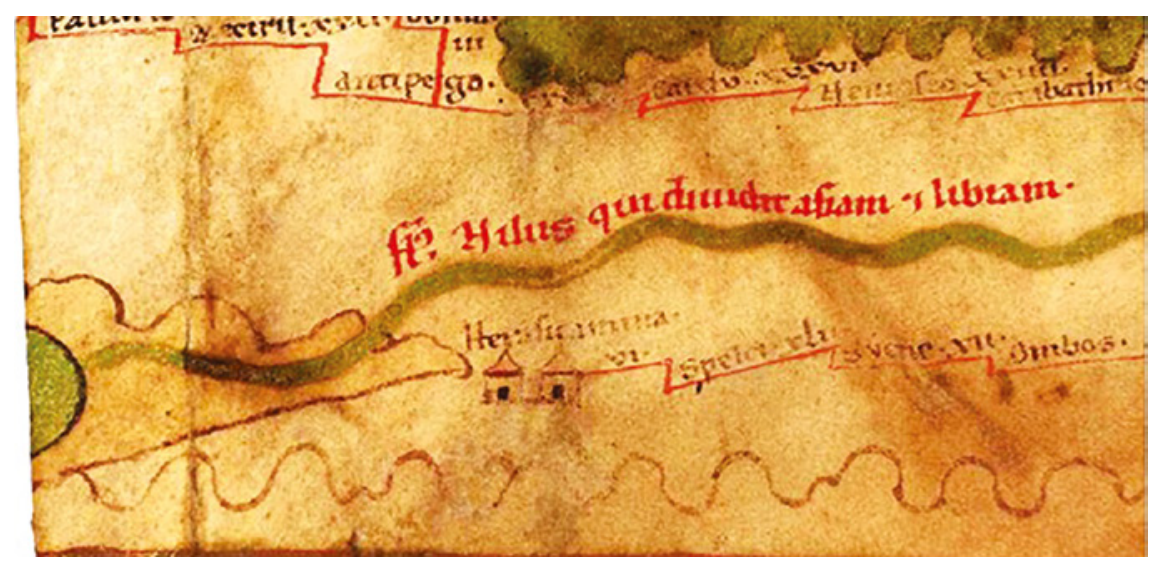

FIGURE 20.8B River Nile divides Asia and Libya

additions. Many scholars felt that the mountain symbols had been drawn with little care, since their representation in the TP is indeed strongly stylized and unified: Regardless to their true shape, they are reduced to ragged stretches, as it is typical for late antique and medieval maps, ${ }^{37}$ with variations in form and color for merely decorative purposes. ${ }^{38}$ The longest of them, Mons Taurus $\left(9 \mathrm{~B}_{1}-11 \mathrm{~B}_{3}\right)$, is labeled twice, towards its end with the inscription MONS IMEVS $\left(11 B_{3}-11 B_{5}\right) \cdot{ }^{39}$ In a long horizontal line (probably an echo of Eratosthenes)

37 For examples see Arnaud 1990, op. cit. (n. 24), 573-574.

38 See Bosio 1983, op. cit. (n. 24), 47-48; Talbert 2010, op. cit. (n. 24), 106-107.

39 See A.V. Podossinov, 'Osteuropa auf der Tabula Peutingeriana. Einige Beobachtungen zu der kartographischen Technik und der geographischen Nomenklatur', Orbis Terrarum 17 (2019), 185-240. 


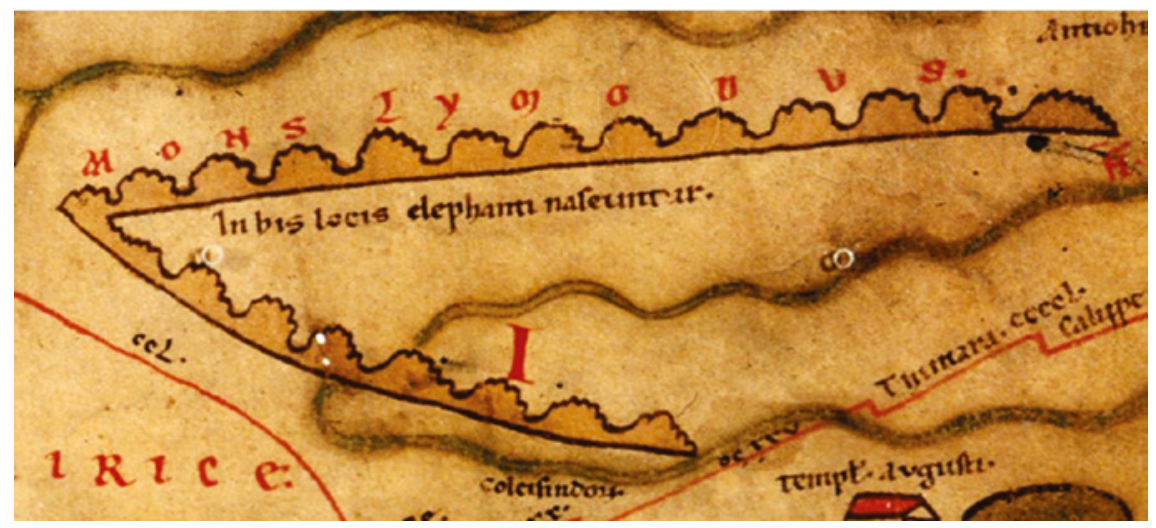

FIGURE 20.9 Elephants living near the mountains

it separates the right quarter of the map horizontally in two parts, like the Alps-Apenine-range on the left side divides Italy $(2 \mathrm{~B} 2-6 \mathrm{~B} 2)$.

The prevailing semantic function of mountain symbols in the TP is the visualization of blockages and barriers, signaled right by the quasi-perspectival shape of their designs, which suggest three-dimensionality. ${ }^{40}$ This might be one reason why they are scarcely named themselves, but more often hinted at in the names of route stops at mountain passes labeled, for instance, In alpe maritima, In alpe iulia or In summo pyreneo, which features them, too, as natural impediments that must be - and can be - overcome.

Sometimes, mountain ranges are eerie places at the rim of the oikumene, infested by strange beasts like elephants (fig. 20.9) "dog-heads" (baboons, 8C5), or scorpions $\left(\mathrm{11}_{3}\right)$. The Christian addition Mons Syna $\left(8 \mathrm{C}_{4} / 5\right)$ is a different case: in Christian thought mountains can be perceived as meeting points between heaven and earth, were revelations might happen: Hic legem acceperunt $i(n)$ monte Syna ("Here on Mt. Sinai they received the law").

A river springing from a mountain-symbol sometimes represents boundary lines. A good example is the river Arsia (Fluvius Arsia 4A1), today Raša, in Istria (fig. 20.10). In the TP, the river Arsia is drawn as a left-hand continuation of an unnamed, strongly stylized brown mountain chain symbol, today Ćićarija. Together, mountain range and river form a borderline between Istria peninsula and the mainland. In fact, though, the Arsia flows right through Istria from north to south parallel to its eastern coast. How can this deviation be explained? The Arsia was, indeed, the border river between Istria and Liburnia. 


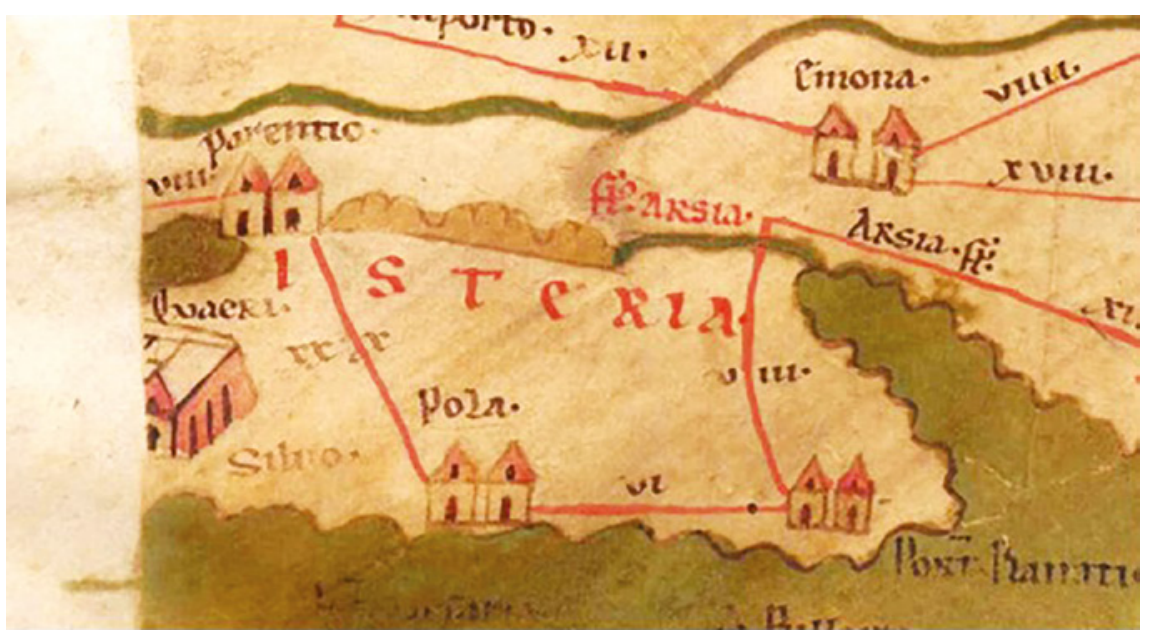

FIGURE 20.10A River Arsia

Moreover, between 18 and $12 \mathrm{BCE}$, during Augustus' expansion of the regio decima to Istria, the Arsia was established as the eastern frontier of Italia. So the mapmaker obviously confounded the physical outlines of Istria peninsula with its political borders, or - he consciously made them coincide, so that this administrational division looks much more like a natural one.

Another example is the river Acheloos (6B 4 Acilovm Fl.), which springs from Mount Lakmon in the Pindos mountain range. During the Imperial period, the Acheloos separated the provinces Epirus and Achaea (Ptol. 3.13f). In the TP, the (unnamed) Mount Pindos has been extremely elongated to form, together with Acheloos river, a neatly fitting 'natural' borderline. Similar examples are the rivers Drilo $\left(6 \mathrm{~A}_{1} / 2\right)$, Hippus $\left(5^{\left.A_{3}\right)}\right.$, Savus $\left(3^{A_{5}-5} A_{4}\right)$, Haliacmon $\left(6 B_{5}\right)$, Strymon $\left({ }_{7} \mathrm{~B} 1 / 2\right)$ and many more.

In the text passage quoted above (2.5.17), Strabo describes landscape in terms of a painting designed by personified landscape elements like seas, rivers and mountains, which, along with cities, are characterized as 'ornaments' ( $\left.\pi \circ x^{\prime} \lambda \mu \alpha \tau \alpha\right)$. In the TP playful embellishments abound, for instance, the Triton's horn ${ }_{7} \mathrm{C}_{4} \mathrm{f}$ lacus Tritonum) (fig. 20.11 ) and the Nile Delta $\left(8 \mathrm{C}_{3} / 4\right)$ (fig. 20.12), with sanctuaries inserted like gems between the river branches, or the falciform bay in ${ }_{7} \mathrm{~B} / \mathrm{C}$, shaped in correspondence with the African Syrtes on its right $\left({ }_{7} \mathrm{Cr} / 2\right)$. The islands and archipelagoes, too, are placed neatly in 


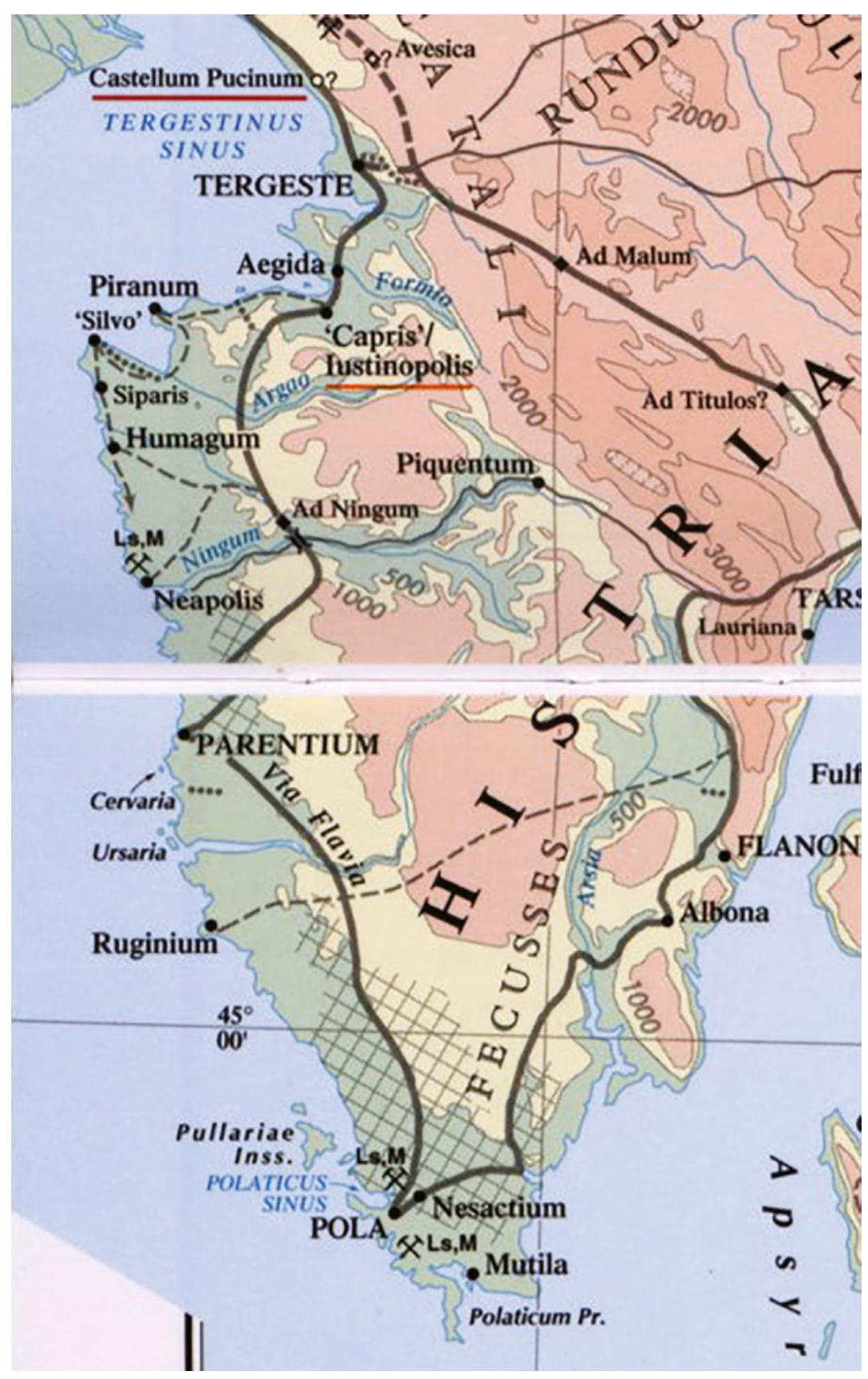

The River Arsia, in: R.J.A. Talbert, Barrington Atlas of the Greek and Roman World, Princeton et al. 2000, Map 20; concession was given to DFG-project "Kommentar zur Tabula Peutingeriana/Commentary on the Tabula Peutingeriana" of S. Diederich and M. Rathmann 
equal distances like pearls on a chain, with little regard to their natural shape and position. ${ }^{41}$ This dissolution of landscape into the ornamental reminds us that the world is a kosmos, a mundus in the double sense of the word.

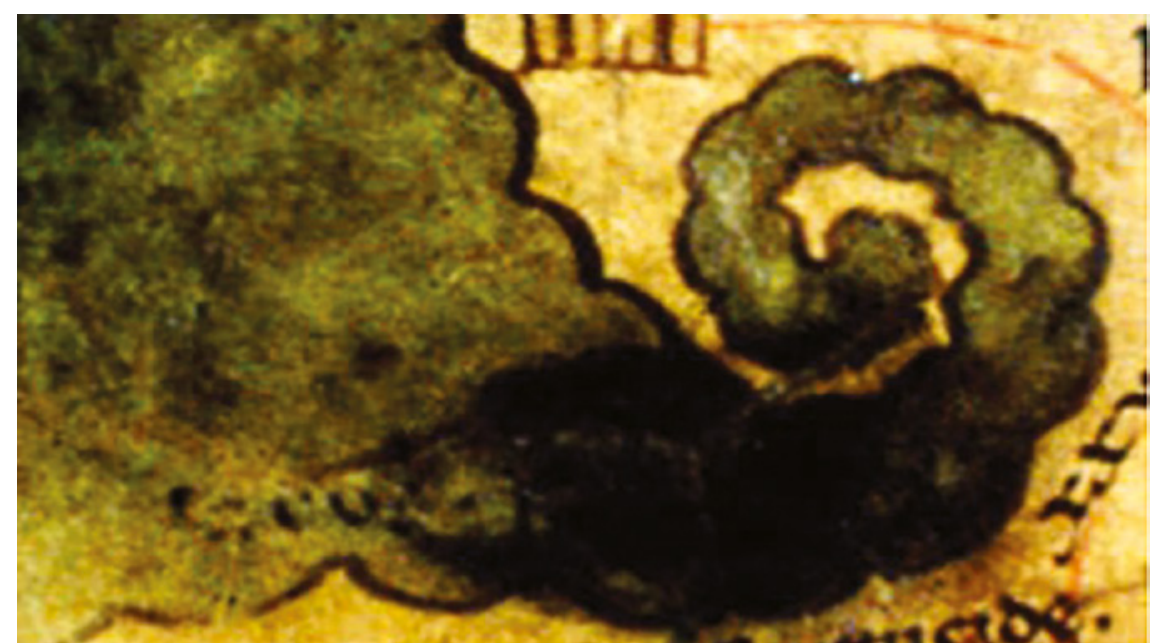

FIGURE 20.11 Triton's horn

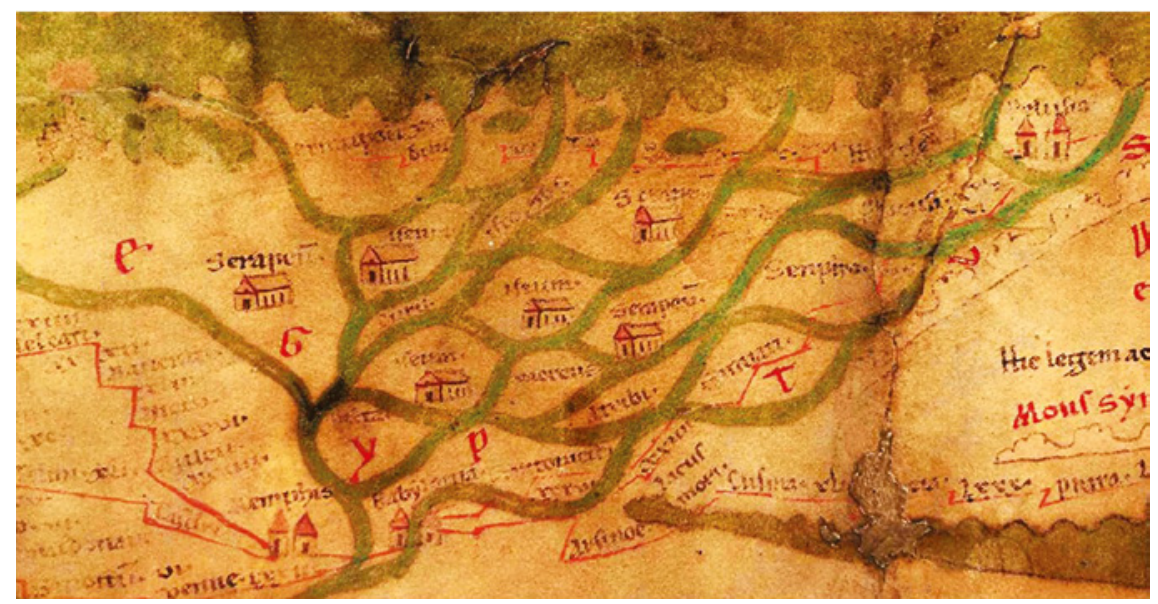

FIGURE 20.12 Nile delta

41 Cf. Apul. mund. 1. 
11 Roads

Roads, being crucial for organizing imperial space, have, accordingly, a prominent place in the TP. Lined out in flashy red, they span the whole oikumene from one end to the other, mounted with roughly 35 oo road stations with distance figures between them.

This prompted scholars to jump to the conclusion that the TP was meant as a travelling map, an iterarium pictum. Recent research, however, has confuted this hypothesis, since micro analyses have evinced that those roads did indeed exist, but not all at the same time. Thus, the elaborate route system outlaid in the TP purports an idealized and anachronistic completeness, which in this form never existed. ${ }^{42}$ Even from this fact alone it is obvious that the map could not have been used as an itinerary, the more so as it is not even always clear whether the measuring unites applied were miles, stadia, leugae or parasangs.

Nevertheless, all those thousands and thousands of itemized road miles convey a message: of how the world has been diligently measured out by the Roman rulers. As Neopythagorean numerology and number mysticism had deeply influenced ancient thought, both pagan and Christian, this numeration of the world may have had an almost mystical ring, for, according to this wide-spread believe system, numbers are the principle of all things existing, the quintessence of cosmic order. Accordingly, assigning numbers to places means homologizing the uncanny, shapeless wilderness of landscape with this cosmical order.

In the TP, Rome is not placed in the center (even if more than one segment on the left should be missing, which is unlikely). ${ }^{43}$ Rather, there seems to be a

42 This was one of the results of the conference on the TP in Vienna in September 2019 Die Tabula Peutingeriana: Aktuelle Forschungsansätze und neue Ergebnisse”. For a conference report see https://www.hsozkult.de/conferencereport/id/tagungsberichte-8594?utm _source $=$ hskhtml\&utm_medium $=$ email\&utm_term $=2020-1 \& u t m \_c a m p a i g n=h t m l$ digest\&utm_source=hskhtml\&utm_medium $=$ email\&utm_term $=2020-1 \& u$ tm_cam paign=htmldigestand (last accessed on March 26, 2021. Articles are forthcoming in the periodical Orbis Terrarum).

43 Perhaps the missing left sheet was not entirely covered by the western end of map, as Talbert 2010, op. cit. (n. 24), 88 takes into consideration, as there might have been some combination of caption, list, and dedication. 
balance between Roma (4B5) and Constantinopolis (8A/B), both adorned with magnificent vignettes of about the same size, Roma positioned slightly below the middle, Constantinopolis above, although it actually lies further south than Rome (fig. 20.13). Constantinopolis, forming an ensemble with 8A1 Sycas/ Sykai and other harbor cities on both sides of a strongly inflated Bosporus and Golden Horn ${ }^{44}$ is represented as dominating the sea as Rome dominates the roads. ${ }^{45}$ This balance between the western and the eastern part of the Empire is underlined by the layout of the land bodies: the strongly prolongated Thracia is shaped at its right end $(8 \mathrm{Ar} / \mathrm{Br})$ like the heel of the bootlike Italy in $6 \mathrm{~A} /$ $\mathrm{B} 1-6 \mathrm{~A} / \mathrm{B} 2$. The hose-shaped Thracia itself has a prolongation in the east of the Bosporos in a likewise elongate Asia Minor between the squeezed Black and Mediterranean Seas (fig. 20.1), converging with the Island of Cyprus (beginning in $9 \mathrm{~B} / \mathrm{C} 2$ ) right to the conspiciously decorated Antiochia with a vignette as large and splendid as Rome's and Constantinople's, figuring as the gateway to the east. ${ }^{46}$ Underneath these landmasses, we find four large islands/penisulas of similar size and shape: Sicilia beneath southern Italy (beginning in ${ }_{5} \mathrm{C}_{5}$ ), the Peloponnesos under Macedonia (beginning in $6 \mathrm{~B} / \mathrm{C}_{4}$ ), Insula Cretica (Kreta) beneath Thracia and Asia (beginning in $7 \mathrm{~B}_{4}$ ), and Cyprus. In the horizontal tripartition of the world by the seas, the heartlands of the eastern and the western empire lie, not surprisingly, in the middle.

\section{Conclusion: The Empire's Landscape in the TP}

Having worked out some of the internal semantics of the Tabula and its 'grammar', we are able to 'read' its narrative of an 'imperial' landscape: In this map, the whole oikumene, from west to the farthest east, appears as an allaccessible, well organized space under the beneficial care of Roman rulers. ${ }^{47}$ It is domesticated and civilized by an elaborate, nota bene, idealized road net and thousands of villages, towns and cities, except for those areas, which are

44 Nearly all parts of the sea are strongly narrowed in the TP, except the Bosporus, which "is made broader than necessary, and thereby emphasized", Talbert 2010, op. cit. (n. 24), 89 .

45 For literature see https://tp-online.ku.de/trefferanzeige.php?id=1178 (last accessed on March 26, 2021).

46 Residence of Constantius II, Julian, Jovian und Valens, enlarged ca. 438 CE by Theodosius II, see G. Brands, Antiochia in der Spätantike: Prolegomena zu einer archäologischen Stadtgeschichte (Berlin 2016), 30-31 (see https://tp-online.ku.de/trefferanzeige.php?id=1491, last accessed on March 26, 2021).

See Talbert 2010, op. cit. (n. 24), passim who dates the map under the reign of Diocletian. 


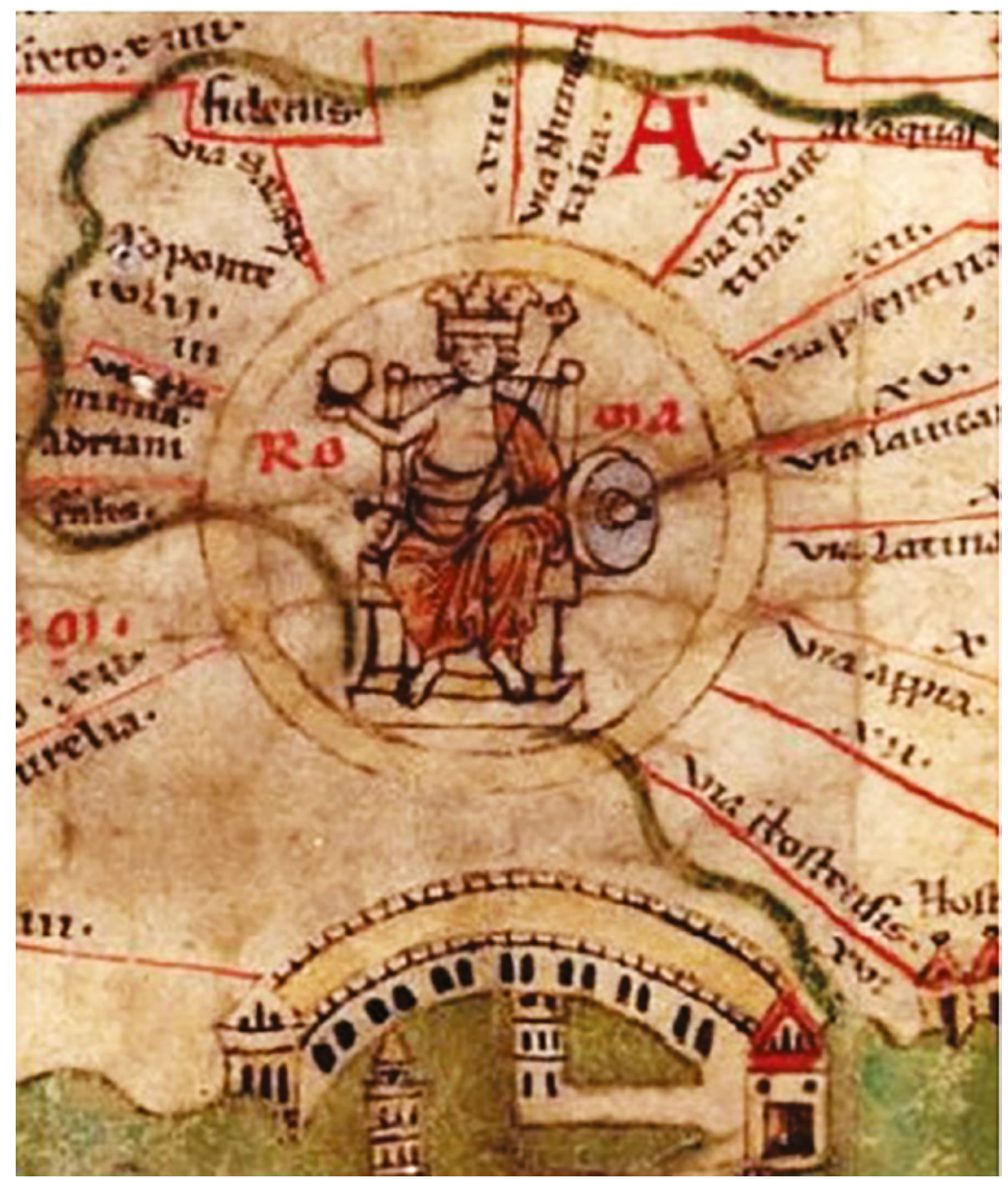

FIGURE 20.13A Roma

absolutely not worth to be visited. Even forbidding deserts and swamps at the fringes of the world have at least the decency to show a taste for symmetry. As opposed to Agrippa's map, the TP does not display provincial boundary lines. But the mapmaker often hints at them by placing river-mountain systems, modified in their shape for the purpose of making them coincide with administrational borders, as to make them appear completely natural. This implies that Roman rule follows the natural order of things, to the degree that imperial borders seem to merely be the realization of a pattern originally 


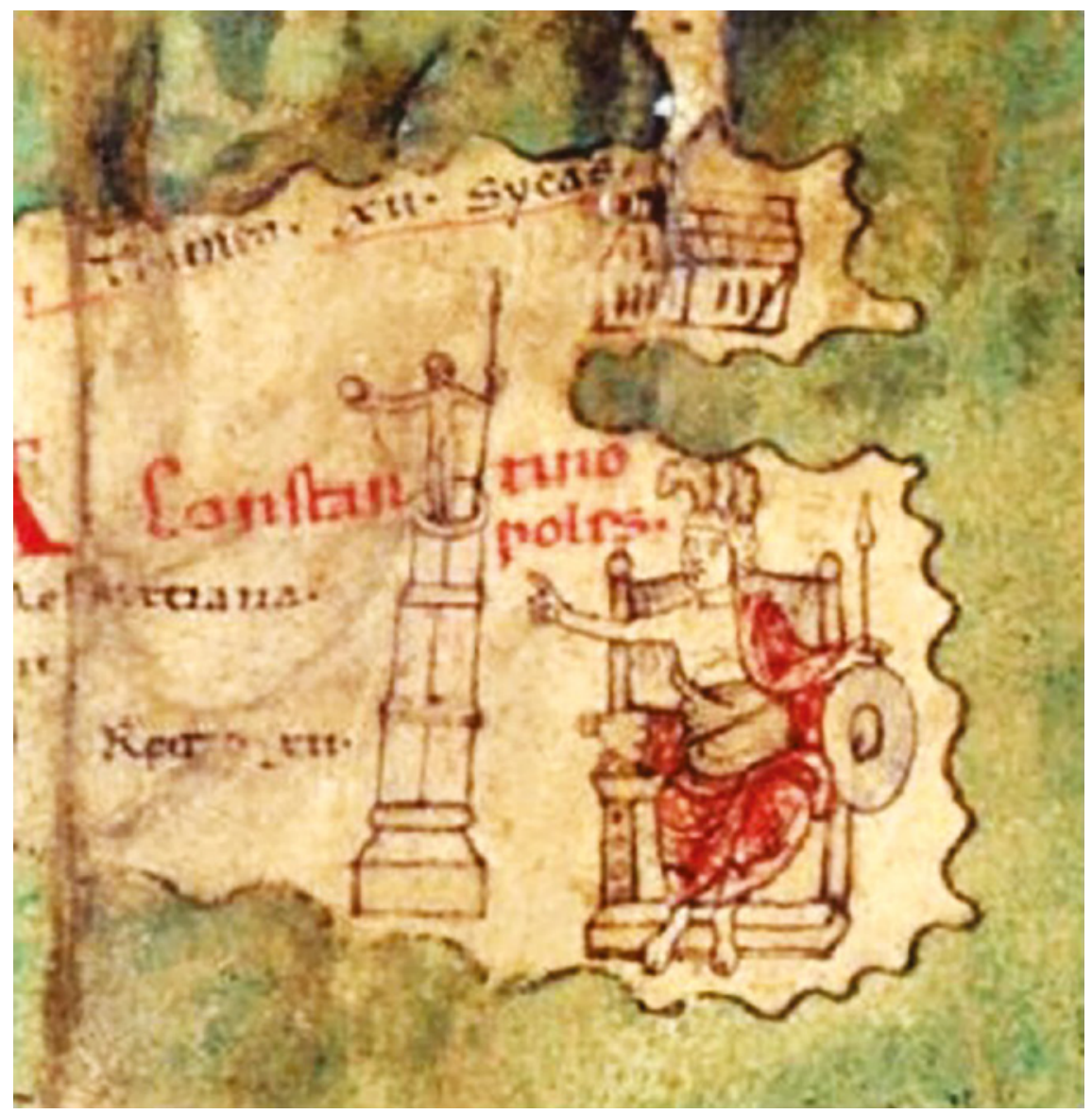

FIGURE 20.13B Constantinople

inscribed into landscape by Nature herself in her wise foresight, as if landscape was created to answer the needs of imperial organization.

The outlay of the landmasses realizes the bipartite unity of Western and Eastern Rome (just like the contemporary Notitia Dignitatum), balancing the greater length of the western part with two large vignettes in the east and a slightly higher position of Constantinopolis. Following the reading direction from left to right as suggested by the map's scroll format, it leads the eye from Rome to Constantinople, visualizing how the center of power shifted from west to east (although Italy, motherland of the empire, remains important). The shapes of landmasses, seas and mountains underline this process as if it all was intended by nature. 


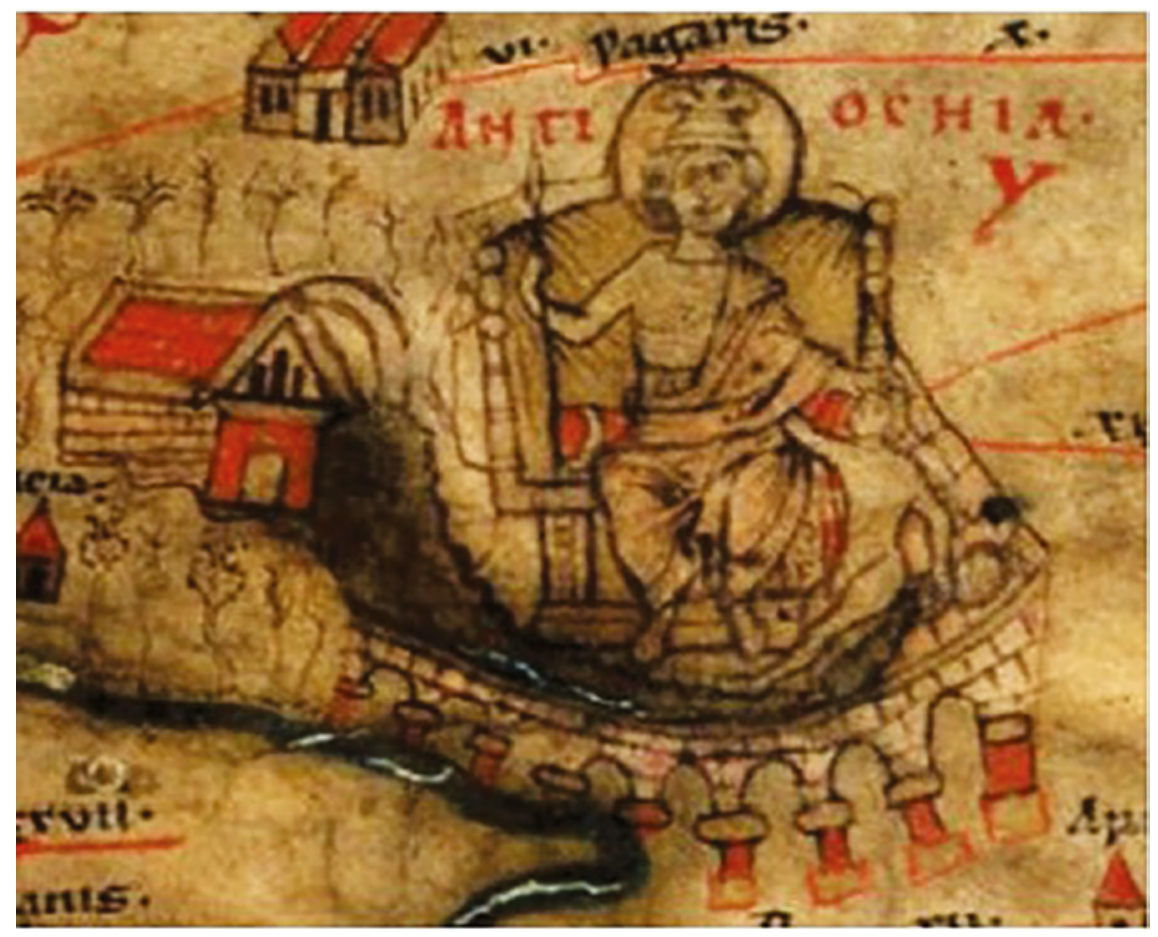

FIGURE 20.13C Antioch

KLe Roma C Constantinopolis Antiochia

FIGURE 20.13D Rome, Constantinople, Antioch

To sum up my hypothesis: The message of the Tabula Peutingeriana is not so much about submitting nature under Roman rule, but it rather tells the story of a Roman Empire ruling the landscapes of the oikumene in concordance with the divine cosmic order. 